\title{
Structure of aquatic vegetation of a large lake, western border of the Brazilian Pantanal
}

\author{
Cunha, NL. ${ }^{a *}$, Delatorre, M. ${ }^{a}$, Rodrigues, RB. ${ }^{b}$, Vidotto, $C^{a}$, Gonçalves, $F^{a}$, \\ Scremin-Dias, E. ${ }^{c}$, Damasceno-Júnior, G. $^{c}$, Pott, VJ. ${ }^{b}$ and Pott, A. \\ aPrograma de Pós-graduação em Ecologia e Conservação, Universidade Federal de Mato Grosso do Sul - UFMS, \\ CEP 79070-900, Campo Grande, MS, Brazil \\ 'Programa de Pós-graduação em Biologia Vegetal, Universidade Federal de Mato Grosso do Sul - UFMS, \\ CEP 79070-900, Campo Grande, MS, Brazil \\ 'Departamento de Biologia, Centro de Ciências Biológicas e da Saúde, \\ Universidade Federal de Mato Grosso do Sul - UFMS, Cidade Universitária, s/n, CP 549, \\ CEP 79070-900, Campo Grande, MS, Brazil \\ *e-mail: nicolaycunha@gmail.com
}

Received August 3, 2011 - Accepted September 16, 2011 - Distributed August 31, 2012

(With 5 figures)

\begin{abstract}
Studies on Neotropical aquatic macrophytes have increased in recent decades, however species richness in wetlands of South America is far from being fully known. In addition, studies having an ecological approach are scarce in the Pantanal. Rapid assessments are essential for gaining knowledge of the biodiversity in the region. This study was performed in five sites of the Baía do Castelo, the western border of the Brazilian Pantanal, which included wild-rice patches, floating mats and floating meadows. At each site, plots of $0.5 \times 0.5 \mathrm{~m}$ were set $(\mathrm{n}=137)$, species of aquatic macrophytes were identified, their coverage was measured and the plot depth was estimated. We recorded 57 species in 26 families, of which Poaceae was the richest. The most frequent and abundant species was Commelina schomburgkiana; the second most frequent was Oryza latifolia,followed by Leersia hexandra, Enydra radicans and Pityrogramma calomelanos. The latter species was second in cover, followed by Pontederia rotundifolia, Eichhornia azurea, E. crassipes and Enydra radicans. These five species and $C$. schomburgkiana (the most abundant) together represent more than half of the coverage on the lake. Pontederia rotundifolia, Ludwigia helminthorrhiza, Pistia stratiotes, E. azurea, E. crassipes, Enydra radicans and Panicum elephantipes were strongly associated with deeper areas, while Oryza latifolia, Leersia hexandra and Salvinia auriculata were prevalent in shallow areas. Pityrogramma calomelanos, Ludwigia nervosa, Ipomoea alba, Cayaponia podantha, Polygonum acuminatum, Rhynchanthera novemnervia and Ludwigia leptocarpa were highly correlated with floating meadows. The structure of the habitat, natural dynamics and zonation of aquatic vegetation in the Baía do Castelo seems to be influenced by a variation in water levels, which promotes spatial segregation, most likely due to competition and/habitat preference.
\end{abstract}

Keywords: aquatic macrophyte, Upper Paraguay basin, phytosociology, Pontederiaceae, wetland.

\section{Estrutura da vegetação aquática em uma grande lagoa, borda oeste do Pantanal brasileiro}

\section{Resumo}

Estudos sobre macrófitas aquáticas Neotropicais aumentaram nas últimas décadas; todavia, a riqueza de espécies em áreas úmidas da América do Sul está longe de ser plenamente conhecida. Além disso, trabalhos com abordagem ecológica são escassos no Pantanal. Por essa razão, levantamentos rápidos são essenciais para o conhecimento sobre a biodiversidade. Este estudo foi realizado em cinco pontos na Baía do Castelo, borda oeste do Pantanal brasileiro, os quais incluíram arrozal, camalotal e baceiros. Em cada ponto, foram estabelecidas parcelas $0.5 \times 0.5 \mathrm{~m}(\mathrm{n}=137)$, onde foram identificadas as espécies de macrófitas aquáticas, estimada a cobertura e tomada a profundidade. Registramos 57 espécies distribuídas em 26 famílias, das quais a mais rica foi a Poaceae. A espécie mais frequente e abundante foi Commelina schomburgkiana; a segunda mais frequente foi Oryza latifolia, seguida por Leersia hexandra, Enydra radicans e Pityrogramma calomelanos. Essa última espécie foi a segunda com maior cobertura, seguida por Pontederia rotundifolia, Eichhornia azurea, E. crassipes e Enydra radicans. Essas cinco espécies juntamente com C. schomburgkiana (a mais abundante) representam mais da metade da cobertura na Baía do Castelo. Pontederia rotundifolia, Ludwigia helminthorrhiza, 
Pistia stratiotes, E. azurea, E. crassipes, E. radicans e Panicum elephantipes foram fortemente relacionadas às áreas mais profundas, enquanto Oryza latifolia, Leersia hexandra e Salvinia auriculata foram relacionadas a areas mais rasas. Pityrogramma calomelanos, Ludwigia nervosa, Ipomoea alba, Cayaponia podantha, Polygonum acuminatum, Rhynchanthera novemnervia e Ludwigia leptocarpa foram altamente correlacionadas com baceiros. A estrutura do habitat, a dinâmica natural e a zonação da vegetação aquática aparentam ser influenciadas pela variação nos níveis d'água na Baía do Castelo, os quais promovem a segregação espacial, provavelmente pela competição e/ou preferência por habitat.

Palavras-chave: áreas úmidas, Bacia do Alto Paraguai, fitossociologia, Pontederiaceae, macrófita aquática.

\section{Introduction}

Aquatic macrophytes are plants visible to the naked eye, which at some point in their life cycle are completely or partially submerged or floating in freshwater (Cook, 1996). They play an ecological role as food, shelter and as nesting sites for various species, as well as nutrient cycling (Esteves, 1998; Petry et al., 2003; Thomaz et al., 2008; Padial et al., 2009). Studies on Neotropical aquatic macrophytes have increased in recent decades. One of the reasons is the recognition of their importance to aquatic ecosystems (Padial et al., 2008). However, species richness in different wetlands of South America is far from being fully known (Ferreira et al., 2011). For this reason, rapid assessments are absolutely essential for evaluating the state of biodiversity (Maltchik and Callisto, 2004), especially in large and species rich wetlands such as the Pantanal. In addition, studies with a predictive approach aiming to test ecological hypotheses, which are necessary to any real attempt at conservation, are rare in the Neotropics (Padial et al., 2008).

Neotropical wetlands vary considerably in the composition of macrophytes, probably due to seasonal variations in water levels and habitat diversity (Ferreira et al., 2011). In seasonally flooded areas, the flood pulse is especially important for these ecosystems (Junk et al., 1989, 2006), because it causes changes in richness and composition of aquatic macrophytes (Maltchik et al., 2007; Santos and Thomaz, 2007; Pitelli et al., 2008; Thomaz et al., 2009; Mormul et al., 2010; Ferreira et al., 2011). The distribution and establishment of aquatic macrophytes in wetlands are mostly determined by abiotic variables such as depth, water current, velocity and its physical and chemical characteristics, solar radiation, turbidity, connectivity to other water bodies and distance from the shore (Frey, 1995; Pott and Pott, 2003; Fortney et al., 2004; Neiff et al., 2005; Santos and Thomaz, 2007; Boschilia et al., 2008; Franklin et al., 2008; Pitelli et al., 2008; Santos and Thomaz, 2008; Mormul et al., 2010; Bornette and Puijalon, 2011; Ferreira et al., 2011).

In the Pantanal, there are approximately 280 species of aquatic macrophytes (Pott et al., 2011), however most studies are only floristic (Prance and Schaller, 1982; Da Silva and Pinto-Silva, 1989; Pott et al., 1989; Frey, 1995; Pott and Pott, 1997, 2000). Some approach the biology and evolutionary aspects of specific plants (James et al., 2001; Cunha and Fischer, 2009; Bertazzoni and Damasceno-
Junior, 2011), while others focus on dynamic, successional process and a quantitative approach of aquatic vegetation in the region (Pinder and Rosso, 1998; Fortney et al., 2004; Pivari et al., 2008). However, as far as we know, there are no studies correlating aquatic macrophytes composition with abiotic factors in the large lakes of the Paraguay sub-region of Pantanal.

Here, we sought to identify what are the aquatic macrophytes species, their incidence and relative coverage in a large lake of the Pantanal wetlands; and evaluate the effects of water depth on species composition of aquatic plants in this lake.

\section{Material and Methods}

\subsection{Study site}

The Brazilian Pantanal, located in the hydrographic basin of the Upper Paraguay River, occupies approximately $138,000 \mathrm{~km}^{2}$. It presents climate, floristic, topographic and soil variations, which, together with the influences of the adjacent phytogeographic domains, divide the lowland in 11 sub-regions (Silva and Abdon, 1998), including the sub-region of Paraguay where the study site is located (Figure 1).

The study was carried out in the Baía do Castelo lake, near the border between Brazil and Bolivia (Calheiros et al., 2000), municipality of Corumbá, Mato Grosso do Sul, Brazil. Baía do Castelo (12,800 ha) is a floodplain lake connected to the Paraguay River and to streams from nearby mountains. The region has a dry winter and rainy summer, with a mean annual rainfall of $1,070 \mathrm{~mm}$ (Soriano, 1997). The flood peak is reached during the dry season, with fluviometric low levels during the rainy season (Damasceno-Júnior et al., 2004) due to delays in the flow coming from the headwaters.

\subsection{Data collection}

On June 1, 2009 five major sites were determined within the Baía do Castelo, which were sampled with the help of a motor boat. The studied sites were classified as: "wildrice" (18 $35^{\circ} 15^{\prime \prime} \mathrm{S}$ and $57^{\circ} 32^{\prime} 35^{\prime}$ ' W), an area visually predominated by wild-rice Oryza spp.; floating mat (two sites - $18^{\circ} 34^{\prime} 34^{\prime \prime} \mathrm{S}$; $57^{\circ} 33^{\prime} 40^{\prime \prime} \mathrm{W}$ and $18^{\circ} 34^{\prime} 35^{\prime \prime} \mathrm{S}$; $57^{\circ} 33^{\prime} 33^{\prime}$ ' W), the border of one wild-rice and bank of the canal that connects the Baía do Castelo Lake to the 


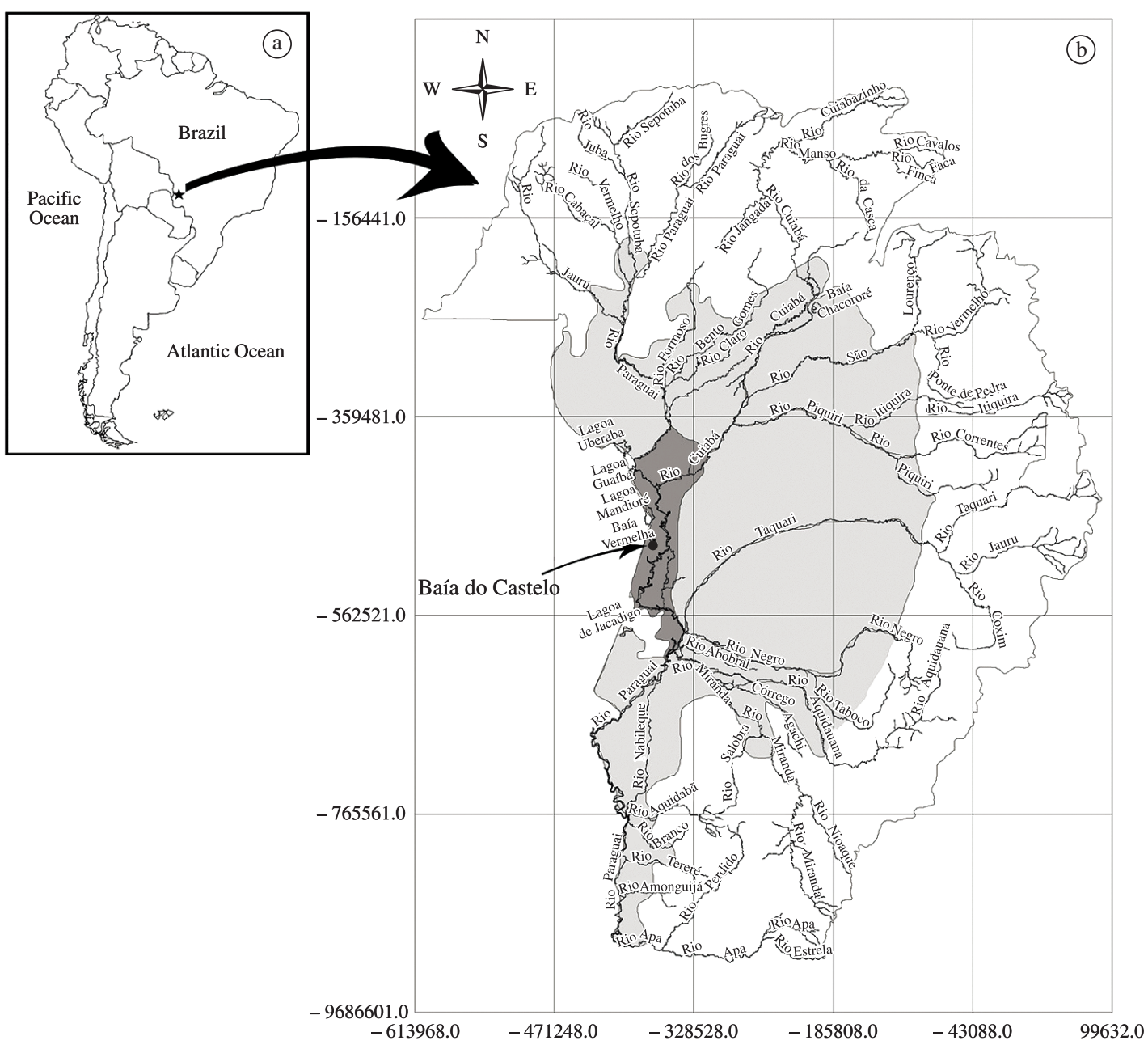

Figure 1. Location of the Brazilian Pantanal in South America (a) and its delimitation in grey according to Silva and Abdon 1998 (b). The studied area is located in the sub-region of Paraguay (dark grey), Pantanal, Corumbá, Mato Grosso do Sul, Brazil (modified from Silva and Abdon, 1998).

Paraguay River, respectively, sites mainly composed by Pontederiaceae and Polygonaceae; and floating meadow (two sites - $18^{\circ} 34^{\prime} 22^{\prime \prime} \mathrm{S}$; $57^{\circ} 33^{\prime} 23^{\prime \prime} \mathrm{W}$ and $18^{\circ} 32^{\prime} 51^{\prime \prime} \mathrm{S}$; $57^{\circ} 34^{\prime} 19^{\prime \prime} \mathrm{W}$ ), which are islands of floating vegetation (see Pivari et al., 2008). At each site, paired transects were parallelly established $1 \mathrm{~m}$ apart (width of the boat). Transects started near the lake open water in direction to the shore, and consisted of entering the aquatic vegetation. On each side of the boat, plots of $0.5 \times 0.5 \mathrm{~m}$ (distant three meters) were set. This process was repeated until it was possible to enter with the boat, and was re-initiated $20 \mathrm{~m}$ away. The total number of transects varied from 5-20 among sites. In the floating meadows, transects of approximately $2 \mathrm{~m}$ apart, were established crossing the whole vegetation island, and plots were set along each transect, $2 \mathrm{~m}$ from each. The number of transects and plots per transect varied within the floating meadow size.

In each plot, we identified the species and visually estimated the percentage of coverage, as well as measured the depth with a rod $(\mathrm{cm})$. The sampling effort in each site was: "wild-rice 1" = 40; "floating mat 1" (border) = 20; "floating mat 2" = 20; "floating meadow 1" = 32 and "floating meadow 2 " = 25, totaling 137 plots $\left(34.72 \mathrm{~m}^{2}\right)$. Vouchers were collected and deposited in the herbarium CGMS (UFMS), Campo Grande, MS. Botanical identification was based on Pott and Pott (2000), updated to APG III (Chase and Reveal, 2009).

\subsection{Data analysis}

The assemblage of each sampled site and the whole assemblage of the study were ranked according to the cover of each species and absolute frequency (species incidence throughout the plots). The sampling effort estimate was analyzed via sample-based rarefaction curves (species accumulation curves); and richness estimate via Jackknife 1 and Chao 1, all methods with 1000 randomizations (Colwell, 2009). All these analysis were performed with each plot as a sample unity. 
The dimensionality of aquatic plant assemblage was reduced using principal coordinates analysis (PCoA), based on the standardized matrix of relative abundance of coverage of aquatic plants in each plot, using the association index of Bray-Curtis. Ordination was used to capture the pattern presented by the most abundant species, because these have the largest contributions to differentiate plots. To determine how much information was recovered from the original distances, a linear regression analysis between the final ordination distances with the real distances (Bray-Curtis matrix) was made, which generated a correlation coefficient $\left(\mathrm{r}^{2}\right)$. To determine the choice of dimensionality, the obtained value was compared with $\mathrm{r}^{2}$ 's generated by the ordination in one and two dimensions.

The resulting ordination axis, which describes the assemblage composition, was used as dependent variables in the inferential tests. An analysis of multivariate variance (MANOVA) was used, with a depth as an independent variable. We did not compare the species composition statistically among the five sampled sites due to incomplete independence among these areas. The rare factions and richness estimative were made using the software EstimateS (Colwell, 2009). All other statistical analysis and graphs were made using the $\mathrm{R}$ software ( $\mathrm{R}$ Development Core Team, 2010) with Vegan package (Oksanen et al., 2009).

\section{Results}

We recorded 57 species of aquatic plants, distributed in 44 genera and 26 families (Table 1). The richest family was Poaceae ( 9 spp.), followed by Asteraceae, Convolvulaceae, Fabaceae, Onagraceae and Polygonaceae (4 spp. each), and Pontederiaceae (3 spp.). Other families presented only two or one species (Table 1). The most frequent species was Commelina schomburgkiana (43\% of all plots); second was Oryza latifolia $(\sim 30 \%)$, followed by Leersia hexandra (28\%), Enydra radicans (26\%), Pityrogramma calomelanos (25\%), Cayaponia podantha and Vigna lasiocarpa (22\% each). Frequency of the other species was below 20\% (Figure 2a). Among the species recorded once were Aeschynomene fluminensis, Alternanthera aquatica, Cecropia pachystachya, Cyperus haspan, Eupatorium candolleanum, Hibiscus striatus, Hydrocotyle ranunculoides, Melochia arenosa, Mimosa pigra, Odontocarya tamoides and Oryza glumaepatula (Figure 2a). Commelina schomburgkiana presented the highest coverage (17\%) among recorded species in the Baía do Castelo, followed by P. calomelanos ( $10 \%)$, Pontederia rotundifolia $(\sim 8 \%)$, Eichhornia azurea, E. crassipes and Enydra radicans, with barely $7 \%$ each. These six species together, represent $56 \%$ of all vegetation coverage recorded within the 137 plots (Figure 2a).

Comparing the sampled sites, "wild-rice 1" was the richest with 34 species (Figure 2b). Oryza latifolia and Salvinia auriculata occurred in $55 \%$ of plots, Ricciocarpus natans, exclusive of this site, presented the third highest absolute frequency (35\%); while incidence of Lemna aequinoctialis, $P$. rotundifolia, E. crassipes and
L. hexandra varied from 25 to $32.5 \%$ (Figure $2 b$ ). Unique species recorded only in this site were A. fluminensis, $H$. striatus and M. pigra. In the same site, species with the highest coverage were $P$. rotundifolia $(38 \%), O$. latifolia $(17.7 \%)$, L. hexandra $(7.7 \%)$, E. crassipes $(7.4 \%)$ and S. auriculata ( $5 \%)$, adding up to about $76 \%$ of coverage.

In the "floating mat 1 " we recorded 26 species (Figure 2c). Commelina schomburgkiana presented the highest frequency (75\%), followed by E. radicans $(70 \%)$; Rhabdadenia madida and V. lasiocarpa (35\% each), E. azurea and E. crassipes ( $30 \%$ each); and C. podantha, Ipomoea alba and Panicum elephantipes with $25 \%$ each. Other species presented an incidence below $20 \%$ each. Oryza latifolia was once recorded at this point, and there were no exclusive species at this site. The species with the highest cover were Commelina schomburgkiana $(24.3 \%)$, E. azurea $(16.5 \%)$, E. radicans $(16.3 \%)$ and E. crassipes (14.2\%), which together correspond to $71 \%$ total coverage. The sites "floating mat 2 " and "floating mat 1" presented 26 species each, and had C. schomburgkiana as the most frequent (70\%), followed by E. radicans $(60 \%)$ (Figure 2d). There was no exclusive species at this site. Commelina schomburgkiana once again had the highest coverage ( 25\%); E. radicans, Eichhornia azurea and E. crassipes presented similar values of coverage (15 to $17 \%$ ), and other species had less than 5\% each (Figure 2d).

"Floating meadow 1" was the second richest when compared with other sites (29 spp.; Figure 2e). The most frequent species were Pityrogramma calomelanos $(56.3 \%)$ and $I$. alba (53.1\%). Leersia hexandra, Caperonia castaneifolia and $O$. latifolia were also quite frequent $(37.5 \%, 31.3 \%$ and $25 \%$, respectively). Melothria fluminensis, Polygonum hydropiperoides, P. punctatum, Cecropia pachystachya and Melochia arenosa were only recorded at this site. Pityrogramma calomelanos presented the highest coverage $(24.3 \%)$, followed by I. alba $(11.7 \%)$, Ludwigia nervosa $(7.7 \%)$ and C. castaneifolia $(6.6 \%)$, these species represent $50 \%$ of cover on this floating island. The remaining species showed values of coverage equal to or less than $5 \%$. In "floating meadow 2 ", unlike what was reported in "floating meadow 1", the most frequent species was C. schomburgkiana (92\%), and the second and third were $P$. calomelanos and $C$. podantha with 68 and 60\%, respectively (Figure 2f). Leersia hexandra and Polygonum acuminatum were present in almost $50 \%$ of the plots. Rhynchanthera novemnervia was exclusively recorded on floating meadows. Furthermore, this site had six unique species - Urochloa arrecta, C. haspan, E. candolleanum, Hydrocotyle ranunculoides, $O$. tamoides and Oryza glumaepatula. Commelina schomburgkiana again had the highest coverage (35\%), followed by P. calomelanos (15\%), V. lasiocarpa (8.7\%) and Ludwigia leptocarpa (7.4\%), while the remaining species presented cover values lower than $5 \%$.

The accumulation curve did not demonstrate stability with the applied sampling effort. The estimative of species richness, based on Jackkinfe 1 and Chao 1, points out the occurrence of, respectively, $68 \pm 4.7$ and $62 \pm 4.5$ 
Table 1. List of species, in alphabetical order of families, of aquatic plants in the Baía do Castelo lake, Paraguay sub-region, Pantanal, with respective habit.

\begin{tabular}{|c|c|}
\hline Family/ Scientific name & Habit \\
\hline \multicolumn{2}{|l|}{ ACANTHACEAE } \\
\hline Justicia laevilinguis (Nees) Lind. & Emergent herb \\
\hline \multicolumn{2}{|l|}{ AMARANTHACEAE } \\
\hline Alternanthera aquatica (D. Parodi) Chodat & Floating leaved herb \\
\hline Alternanthera philoxeroides (Mart.) Griseb. & Emergent herb \\
\hline \multicolumn{2}{|l|}{ APOCYNACEAE } \\
\hline Rhabdadenia madida (Vell.) Miers & Emergent herb \\
\hline \multicolumn{2}{|l|}{ ARACEAE } \\
\hline Lemna aequinoctialis Welw. & Floating leaved herb \\
\hline Pistia stratiotes L. & Floating leaved herb \\
\hline \multicolumn{2}{|l|}{ ARALIACEAE } \\
\hline Hydrocotyle ranunculoides L.f. & Floating leaved herb \\
\hline \multicolumn{2}{|l|}{ ASTERACEAE } \\
\hline Eclipta prostrata (L.) L. & Amphibious herb \\
\hline Enydra radicans (Willd.) Lack & Emergent herb \\
\hline Eupatorium candolleanum Hook. \& Arn. & Epiphyte herb \\
\hline Mikania micrantha Kunth & Epiphyte herb \\
\hline \multicolumn{2}{|l|}{ COMMELINACEAE } \\
\hline Commelina schomburgkiana Klotzsch ex Seub. & Floating leaved herb \\
\hline \multicolumn{2}{|l|}{ CONVOLVULACEAE } \\
\hline Aniseia martinicensis (Jacq.) Choisy & Emergent vine \\
\hline Ipomoea alba $\mathrm{L}$. & Emergent vine \\
\hline Ipomoea carnea Jacq. subsp. fistulosa (Mart. ex Choisy) D. F. Austin & Emergent shrub \\
\hline Ipomoea subrevoluta Choisy & Amphibious vine \\
\hline \multicolumn{2}{|l|}{ CUCURBITACEAE } \\
\hline Cayaponia podantha Cogn. & Amphibious vine \\
\hline Melothria fluminensis Gardner & Emergent vine \\
\hline \multicolumn{2}{|l|}{ CYPERACEAE } \\
\hline Cyperus haspan $\mathrm{L}$. & Amphibious herb \\
\hline Oxycaryum cubense (Poepp. \& Kunth) Lye & Epiphyte herb \\
\hline \multicolumn{2}{|l|}{ EUPHORBIACEAE } \\
\hline Caperonia castaneifolia (L.) A. St.-Hil. & Emergent herb \\
\hline \multicolumn{2}{|l|}{ FABACEAE } \\
\hline Aeschynomene fluminensis Vell. & Emergent subshrub \\
\hline Aeschynomene sensitiva $\mathrm{Sw}$. & Emergent subshrub \\
\hline Mimosa pigra $\mathrm{L}$ & Amphibious subshrub \\
\hline Vigna lasiocarpa (Mart. ex Benth.) Verdc. & Emergent vine \\
\hline \multicolumn{2}{|l|}{ MALVACEAE } \\
\hline Hibiscus striatus Cav. & Emergent subshrub \\
\hline Melochia arenosa Benth. & Emergent subshrub \\
\hline \multicolumn{2}{|l|}{ MARSILEACEAE } \\
\hline Marsilea crotophora D. M. Johnston & Floating leaved herb \\
\hline \multicolumn{2}{|l|}{ MELASTOMATACEAE } \\
\hline Rhynchanthera novemnervia DC. & Emergent subshrub \\
\hline \multicolumn{2}{|l|}{ MENISPERMACEAE } \\
\hline Odontocarya tamoides (DC.) Miers & Emergent vine \\
\hline
\end{tabular}


Table 1. Continued...

\begin{tabular}{|c|c|}
\hline Family/ Scientific name & Habit \\
\hline \multicolumn{2}{|l|}{ ONAGRACEAE } \\
\hline Ludwigia grandiflora (Michx.) Greuter \& Burdet & Emergent vine \\
\hline Ludwigia helminthorrhiza (Mart.) Hara & Floating leaved herb \\
\hline Ludwigia leptocarpa (Nutt.) & Emergent herb \\
\hline Ludwigia nervosa (Poir.) Hara & Emergent shrub \\
\hline \multicolumn{2}{|l|}{ PHYLLANTHACEAE } \\
\hline Phyllanthus fluitans Benth. ex Müll. Arg. & Floating leaved herb \\
\hline \multicolumn{2}{|l|}{ POACEAE } \\
\hline Echinochloa polystachya (H.B.K.) Hitchc. & Amphibious herb \\
\hline Hymenachne amplexicaulis (Rudge) Nees & Emergent herb \\
\hline Leersia hexandra Sw. & Amphibious herb \\
\hline Oryza glumaepatula Steud. & Emergent herb \\
\hline Oryza latifolia Desv. & Emergent herb \\
\hline Panicum elephantipes Nees ex Trin. & Emergent herb \\
\hline Paspalum repens Berg. & Floating leaved herb \\
\hline Paspalum wrightii Hitchc. \& Chase. & Emergent herb \\
\hline Urochloa arrecta (Hack. ex T. Durand \& Schinz) Morrone \& Zuloaga & Amphibious herb \\
\hline \multicolumn{2}{|l|}{ POLYGONACEAE } \\
\hline Polygonum acuminatum H.B.K. & Emergent herb \\
\hline Polygonum ferrugineum Wedd. & Emergent herb \\
\hline Polygonum hydropiperoides Michx. & Amphibious herb \\
\hline Polygonum punctatum Elliot & Emergent herb \\
\hline \multicolumn{2}{|l|}{ PONTEDERIACEAE } \\
\hline Eichhornia azurea (Sw.) Kunth & Floating leaved herb \\
\hline Eichhornia crassipes (Mart.) Solms & Floating leaved herb \\
\hline Pontederia rotundifolia L.f. & Floating leaved herb \\
\hline \multicolumn{2}{|l|}{ PTERIDACEAE } \\
\hline Pityrogramma calomelanos (L.) Link & Amphibious herb \\
\hline \multicolumn{2}{|l|}{ RICCIACEAE } \\
\hline Ricciocarpus natans (L.) Corda & Floating leaved herb \\
\hline \multicolumn{2}{|l|}{ SALVINIACEAE } \\
\hline Azolla caroliniana Willd. & Floating leaved herb \\
\hline Salvinia auriculata Aubl. & Floating leaved herb \\
\hline \multicolumn{2}{|l|}{ URTICACEAE } \\
\hline Cecropia pachystachya Trécul & Arboreous \\
\hline \multicolumn{2}{|l|}{ VITACEAE } \\
\hline Cissus spinosa Cambess. & Emergent vine \\
\hline
\end{tabular}

(mean and standard deviation) species at Baía do Castelo (Figure 3). The 57 recorded species accounted for $81 \%$ of estimated via Jackknife 1 and $91 \%$ of estimated via a Chao 1. Non-aquatic species eventually registered (e.g. C. pachystachya) contributed to extrapolate the estimated richness beyond the properly aquatic flora.

Ordination of quantitative composition of aquatic plant species was best represented in two dimensions by PCoA, which recovered $51 \%$ of the variation from original distances. The species composition was significantly related to depth (MANOVA $_{\text {depth }}, \mathrm{F}_{1,133}=68.47$, Pillai $=0.5092, \mathrm{p}<0.0001$ ).
Pontederia rotundifolia, Ludwigia helminthorrhiza, Pistia stratiotes, E. azurea, E. crassipes, Enydra radicans and Panicum elephantipes were the species most closely related to deeper waters $(\geq 2 \mathrm{~m})$, while $O$. latifolia, L. hexandra and $S$. auriculata were related to shallower ones $(\sim 1 \mathrm{~m})$ (Figure 4 and 5). Pityrogramma calomelanos, L. nervosa, I. alba, C. podantha, P. acuminatum, $R$. novemnervia and Ludwigia leptocarpa had a higher correlation with the floating meadows (Figure 4 and 5). Commelina schomburgkiana was the only species extensively recorded throughout the depth gradient (Figure 5). 

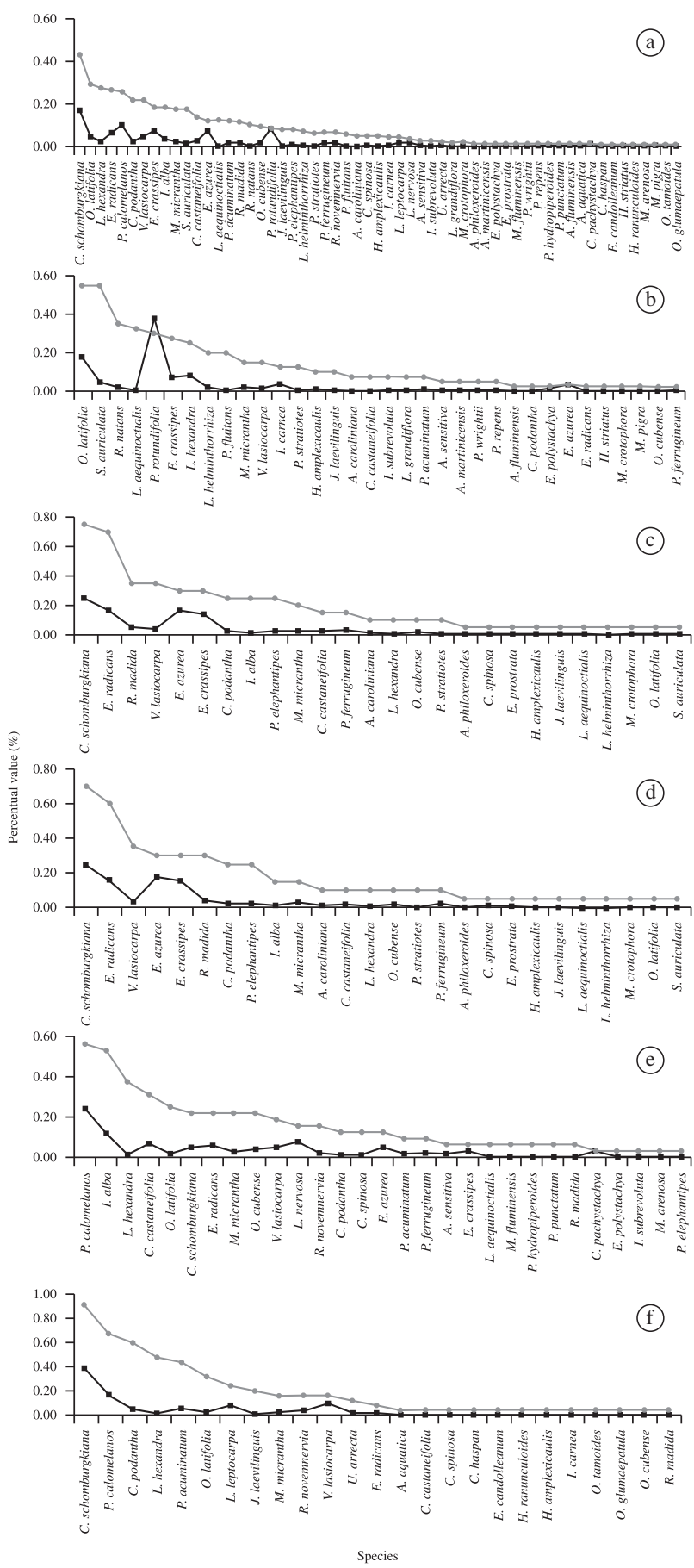

Figure 2. Rank-abundance distribution of recorded species in relation to incidence (grey line with circles) and cover (black line with squares), sampled in different vegetation types in the Baía do Castelo lake. Graphs correspond to: (a) whole sampled assemblage, (b) "wild-rice 1", (c) "floating mat 1", (d) "floating mat 2", (e) "floating meadow 1" and (f) "floating meadow 2".

\section{Discussion}

The richness of 57 species of aquatic plants recorded in the Baía do Castelo Lake during this study corresponds to approximately $20 \%$ of aquatic macrophyte checklist for the entire Pantanal (Pott et al., 2011). Because of the scarcity of studies in the sub-region of Paraguay, which limits local comparisons, species richness found in this study is high when compared to other sub-regions. In Baía Piuval and another lake in the reserve Acurizal 


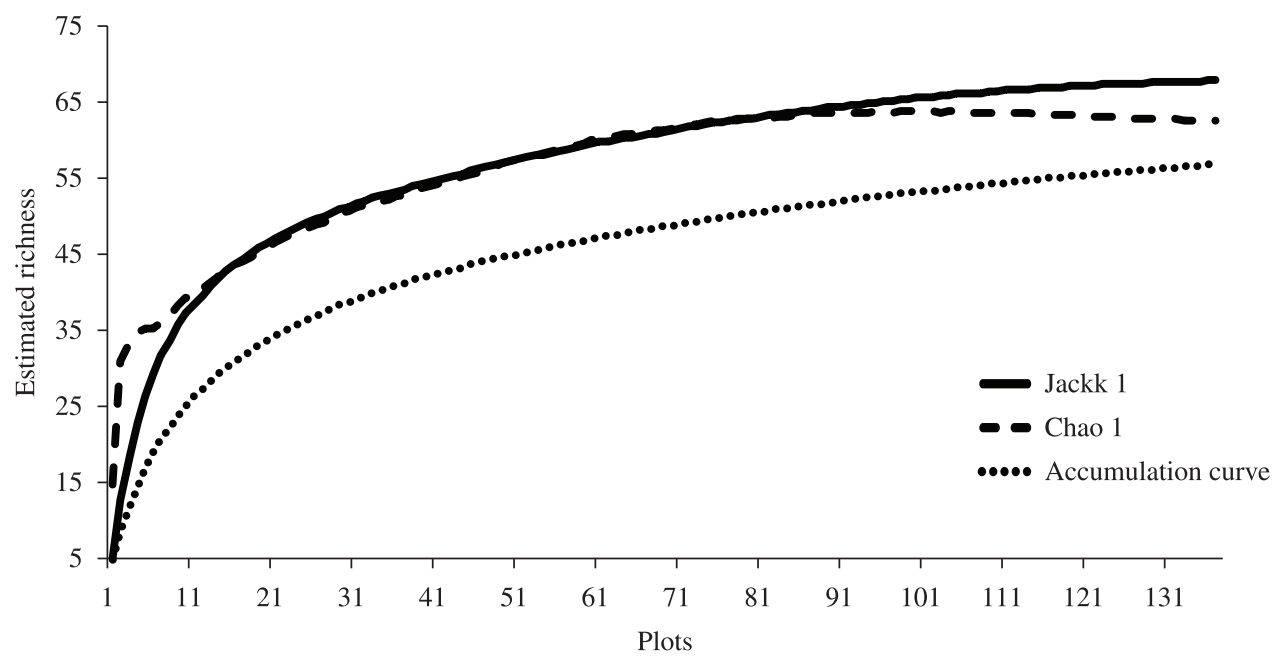

Figure 3. Rarefaction and richness estimate curves based on the incidence matrix of aquatic macrophytes in Baía do Castelo Lake, Paraguay sub-region, Pantanal.

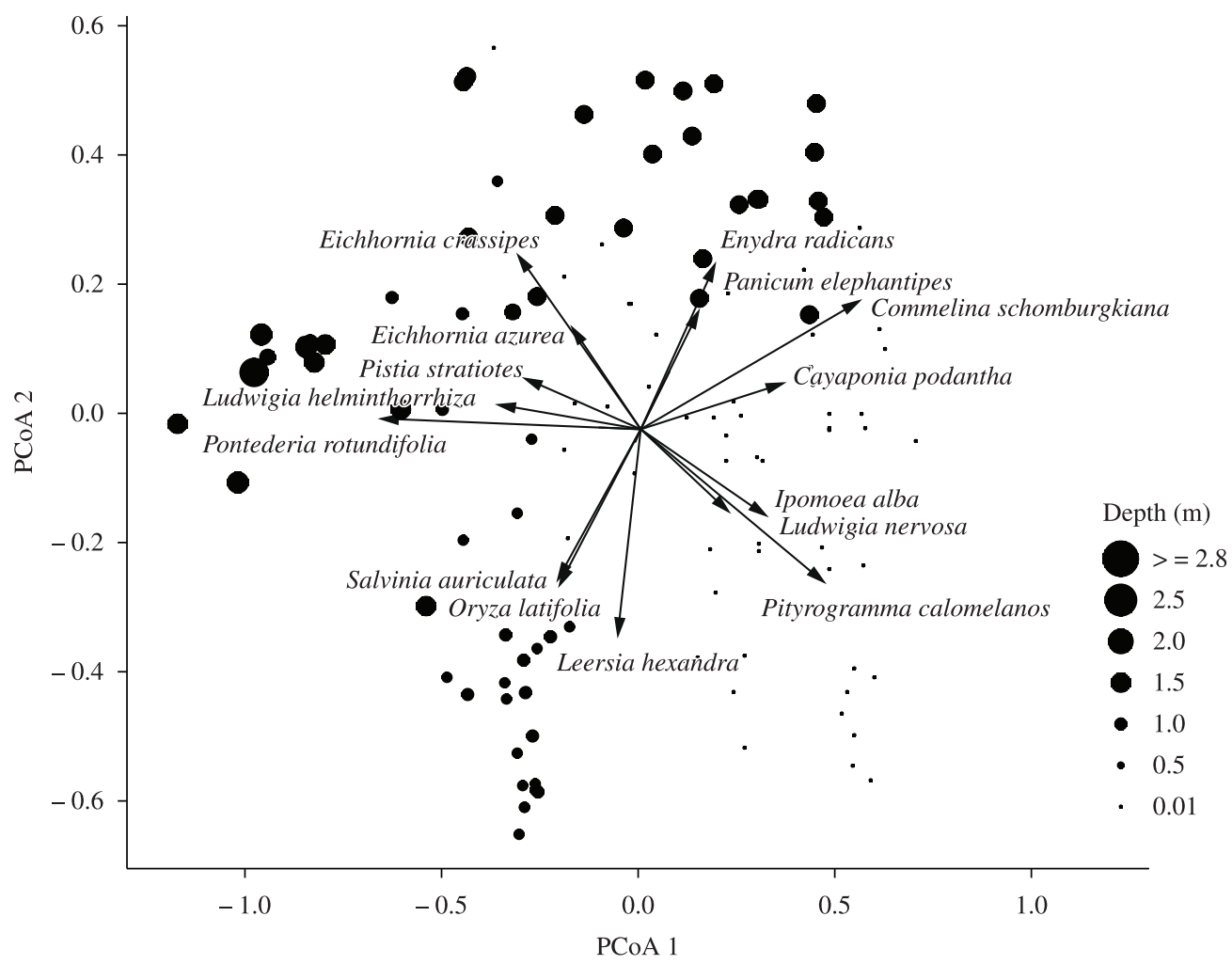

Figure 4. Indirect ordination of 137 plots based on aquatic macrophytes coverage in Baía do Castelo lake, better represented with two principal coordinates - PCoA $\left(\mathrm{r}^{2}=0.51\right.$ explained variance) in relation to depth of plots (MANOVA, $\mathrm{F}_{1,133}=68.47$, Pillai $=0.5092, \mathrm{p}<0.0001)$. Arrows indicate species with higher contributions for point distribution in the graph.

(both in the sub-region of Poconé) only 22 and 18 species were found, respectively (Fortney et al., 2004), while in 20 ponds at Nhumirim ranch (Nhecolândia sub-region) 36 species were reported (Rodrigues, 2010), and in Baía Negra (Miranda-Abobral sub-region) 42 species (Kufner, 2009). On the other hand, in a study conducted in Laguna
Caceres, in the Bolivian Pantanal nearby the town of Corumbá, there were 67 species of aquatic plants (Frey, 1995), having much similarity with this study, however that study included amphibious plants.

Poaceae was the richest family, commonly found among aquatic macrophytes in Pantanal (Pott et al., 2011). Species 

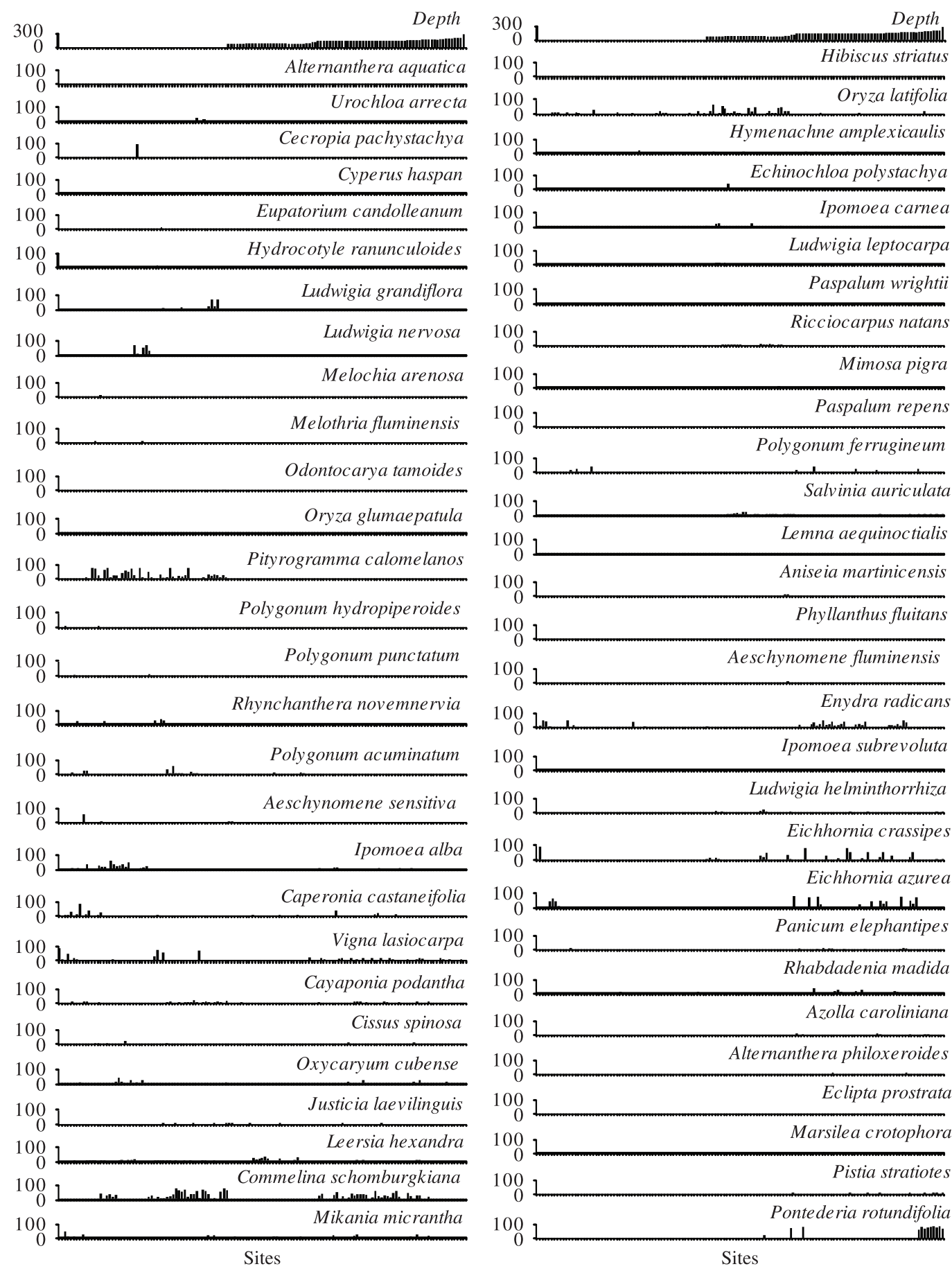

Figure 5. Direct ordination of sampling units, according to the percentage of coverage of aquatic macrophytes throughout the depth $(\mathrm{cm})$ gradient in Baía do Castelo lake, Paraguay sub-region, Pantanal, Corumbá, Mato Grosso do Sul.

of this family are the most frequently reported in various studies on aquatic flora in the Pantanal (Pivari et al., 2008; Kufner, 2009; Rodrigues, 2010) as well as in other flooded regions (Araújo et al., 2002; Guimarães et al., 2002; Pott et al., 2006; Pitelli et al., 2008; Cervi et al., 2009; Kozera et al., 2009; Mormul et al., 2010; Ferreira et al., 2011). The high incidence of grass species in floodplains is probably related to the tolerance to seasonal variations imposed by dry and flood periods, and even being able to present an epiphytic habit, allowing the establishment of other aquatic species (Pivari et al., 2008; Kozera et al., 2009; Rocha and Lins, 2009). Corroborating some surveys of aquatic plants in the Upper Paraguay River Basin, the families Asteraceae, Convolvulaceae, Onagraceae, Polygonaceae and Fabaceae 
were the most species-rich (Pivari et al., 2008; Kufner, 2009; Rodrigues, 2010; Pott et al., 2011).

The richness found in floating meadows in Baía do Castelo (42 spp.) is consistent with other studies in the Pantanal. In the sub-region of Miranda-Abobral, 66 epiphytic species were found in five floating meadows (Pivari et al., 2008), while in the Poconé sub-region just 19 species were reported (Lima et al., 1999). The number of species found in both floating meadows ( 29 and 25 species) may be related to successional stages of the floating islands, because the longer the time of succession, the thicker the histosol and higher species richness (Pivari et al., 2008). The presence of species such as E. azurea in floating meadows suggest that these islands are in an early stage of succession, however the presence of species such as Ludwigia nervosa, Mikania micrantha and $R$. novemnervia are expected in older floating meadows (Pott and Pott, 2003; Pivari et al., 2008). Thus, due to species composition, apparently these floating meadows are in an advanced stage of succession. Nevertheless, because of the presence of some species such as $C$. pachystachya and $R$. novemnervia on relatively small islands, as studied here, we could hypothesize that these "floating meadows" are fragments of larger ones, because with an increasing thickness of histosols, the floristic composition is gradually changed to shrubs and even trees (Pott and Pott, 2003; Pivari et al., 2008).

The species $C$. schomburgkiana presented the highest incidence and coverage for the entire Baía do Castelo and in specific sites such as "wild-rice 2" and "floating mat 2". This species is described as floating leaved herb or, when in floating meadows, rooted which can be supported by other plant species. Frequently found in rivers, "corixos" (seasonal watercourses on old riverbeds) and elsewhere with high nutrient concentration and clay soil (Pott and Pott, 2000), which is somewhat consistent with that found in Baía do Castelo during the sampling period (flood season). However, comparative studies between flood and dry periods are required to confirm whether this species keeps these patterns throughout the year.

Oryza latifolia was the second most frequent species throughout the study and at site "wild-rice 1". In the Pantanal, large areas dominated by species of Oryza are common. These species typically present significant vegetative propagation, which allows for the occurrence of several patches over relatively short distances (Pott et al., 2011). Specifically in the sub-region of Paraguay, they occur in large patches, and are most common and vigorous during the flood period, reaching $5 \mathrm{~m}$ high (2 to $3 \mathrm{~m}$ submerged and 1-2 $\mathrm{m}$ emerged) (Bertazzoni and Damasceno-Junior, 2011). During low water this species prostrates its branches, providing the regrowth of stems at the beginning of the rainy season (Bertazzoni and Damasceno-Junior, 2011), which explains the high frequency of these species.

The species Leersia hexandra and E. radicans were also present in more than $25 \%$ of plots. In Pantanal, L. hexandra establishes itself in several habitats, ranging from floating meadows to temporary or permanent ponds, and flooded grasslands (Pott and Pott, 2000). It propagated by seeds, stolons or rhizomes (Pott and Pott, 2000), which confers a high capacity to spread in various habitats. Enydra radicans presents vegetative propagation, with both submerged and amphibious habit; it is found mainly in macrophyte patches in rivers and floating meadows (Pott and Pott, 2000). This strategy certainly contributed to the increased incidence in sites such as "floating mat 1" and "floating mat 2". Pityrogramma calomelanos is one of the five most frequent species and was the second with more coverage. Usually present in floating meadows (highest incidence and coverage in "floating meadow 1"), this fern is common on borders of lagoons and marshes, it plays the role of pioneer in the process of colonization of areas where the flood caused the death of vegetation (Pott and Pott, 2000). In a study of aquatic macrophytes of floating islands in the Pantanal, this species was only found on islands in an advanced stage of succession. Additional species with a high coverage for the entire study area were $P$. rotundifolia, E. azurea, E. crassipes and Enydra radicans. All the cited Pontederiaceae present significant vegetative propagation and are strongly influenced by environmental changes due to the variation in water level (Prance and Schaller, 1982; Cunha and Fischer, 2009). In addition, during the flood (period of this study), these species are described as dominant and widely distributed because of their high occupation capacity (Prance and Schaller, 1982; Frey, 1995). Overall, the landscape of Baía do Castelo during fieldwork is summarized in the species $C$. schomburgkiana, P. calomelanos, Pontederia rotundifolia, Eichhornia azurea, E. crassipes and Enydra radicans which together represent more than half of all the vegetation cover.

Amongst the unique species of "floating meadow 1" Cecropia pachystachya is worth mentioning as it has an arboreus habit and is considered a pioneer species with rapid growth, which provides favorable conditions for the establishment and development of other plants during the process of ecological succession in floating islands (Pott and Pott, 2003; Pivari et al., 2008). Rhynchanthera novemnervia was restricted to floating meadows. This emergent or amphibious subshrub presents a peak of flowering during the rainy season on dry land, except in floating meadows (where there is no shortage of water), where it flowers all year round (Pott and Pott, 2000). Perhaps, this peculiarity improves its establishment on floating meadows. Nevertheless, $R$. novemnervia was not recorded on floating islands of the Miranda-Abobral sub-region (Pivari et al., 2008).

The sites "floating mat 1" and "floating mat 2" can be considered intermediate habitats compared to other sampled sites. Species composition varied from strictly aquatic species to amphibious and vines, and did not present exclusive species. This environment is likely to receive a strong influence of water level variation, then generalist species in habitat selection should be favored, or just staying there by random action of water current and wind (Boschilia et al., 2008).

Despite the small sampled area and no stabilization of the rarefaction curve, the sampling effort is representative when compared to that estimated for the Baía do Castelo 
lake. The estimated richness was probably not higher ( $\sim 5 \%$ ) because of the occurrence of non-strictly aquatic flora (e.g. C. pachystachya). This high estimated richness strengthens the importance of this list of species for this lake, but it is important to stress that the found richness may be underestimated. Systematic studies using periodic sampling are required to estimate if the found richness is representative of the total richness of the Baía do Castelo, or if this richness, as well as species incidence and cover are modified along the dry and rainy seasons, as described elsewhere (Mormul et al., 2010).

Species composition of aquatic plants was related to depth. Pontederia rotundifolia, Ludwigia helminthorrhiza, Pistia stratiotes, Eichhornia azurea, E. crassipes, Enydra radicans and Panicum elephantipes were strongly related to deeper waters ( $\geq 2 \mathrm{~m}$ ), while $O$. latifolia, L. hexandra and $S$. auriculata were related with shallower areas $(\sim 1 \mathrm{~m})$. Moreover, Commelina schomburgkiana was the only species widely distributed throughout the depth gradient. However, none of the above species was unique to particular depth. The structure of the habitat, natural dynamics of aquatic vegetation and species composition of Baía do Castelo seems to be influenced by the variation in water levels, at least during the sampling period, which promotes spatial segregation, most likely due to competition and/or habitat preference. Generally, these plants can be arranged depending on the degree of connectivity with the river, time of the year, interaction among species and depth of water bodies, as described for floodplains elsewhere (Santos and Thomaz, 2007; Thomaz et al., 2007; Boschilia et al., 2008; Pitelli et al., 2008; Mormul et al., 2010; Bornette and Puijalon, 2011; Ferreira et al., 2011). Pityrogramma calomelanos, L. nervosa, I. alba, C. podantha, $P$. acuminatum, $R$. novemnervia and Ludwigia leptocarpa had higher correlation with the floating meadows, where the plants are not submerged, just their roots are constantly in water. Some populations of aquatic plants enhance their development in shallower environments, although the reduction in water levels limits the occurrence or increases mortality of other species adapted to higher depths (Santos and Esteves, 2004; Pitelli et al., 2008). On the other hand, macrophyte assemblages in floodplains are more heterogeneous in shallow environments (Santos and Thomaz, 2007). This occurs probably because many species are persistent in marshy environments due to their highly competitive ability and are seasonally depleted during the drought, allowing the coexistence of many species of similar habits between the wet and dry periods (Junk et al., 1989; Boschilia et al., 2008).

This study shows strong evidence of change in the assemblage of aquatic plants related to different depths in the Baía do Castelo. The duration and amplitude of water levels might determine the species composition in Baía do Castelo as described elsewhere (Santos and Thomaz, 2007; Boschilia et al., 2008), however the role of fluctuations in water levels in the composition of these aquatic macrophyte assemblages is still unclear. Although we made a single sampling expedition, data reported here are of great value for understanding the patterns of distribution and cover of aquatic macrophytes in the Pantanal.

Acknowledgements - We would like to thank the organization of the "Curso de Campo Ecologia de Plantas Aquáticas", offered by the post-graduate programs in Biologia Vegetal and Ecologia e Conservação (UFMS); monitors Rosa H. Silva and Zildamara R. H. Menegucci, all our colleagues from the course; the great help of our friend and boat pilot, Jocemir Antunes ("Jaburu"), as well as all the crew of Evaldo's boat and ECOA for the logistic support; to J. L. Holladay for the English review, and CNPq and CAPES for grants given to N. L. Cunha, M. N. Delatorre, R. B. Rodrigues, F. Gonçalves, C. Vidotto and A. Pott.

\section{References}

ARAÚJO, GM., BARBOSA, AAA., ARANTES, AA. and AMARAL, AF., 2002. Composição florística de veredas no município de Uberlândia, MG. Revista Brasileira de Botânica, vol. 25 , no. 4 , p. $475-493$.

BERTAZZONI, E. and DAMASCENO-JUNIOR, GA. 2011. Aspectos da Biologia e Fenologia de Oryza latifolia Desv. (Poaceae) no Pantanal sul-mato-grossense. Acta Botanica Brasilica, vol. 25, no. 2. http://dx.doi.org/10.1590/S0102-33062011000200023

BORNETTE, G. and PUIJALON, S., 2011. Response of aquatic plants to abiotic factors: a review. Aquatic Sciences, vol. 73, p. 1-14. http://dx.doi.org/10.1007/s00027-010-0162-7

BOSCHILIA, SM., OLIVEIRA, EF. and THOMAZ, SM., 2008. Do aquatic macrophytes co-occur randomly? An analysis of null models in a tropical floodplain. Oecologia, vol. 156, no. 1, p. 203-214. PMid:18274779.

CALHEIROS, DF., SEIDL, AF. and FERREIRA, CJA., 2000. Participatory research methods in environmental science: local and scientific knowledge of a limnological phenomenon in the Pantanal wetland of Brazil. Journal of Applied Ecology, vol. 37, p. 684-696. http://dx.doi.org/10.1046/j.1365-2664.2000.00524.x

CERVI, AC., BONA, C., MOÇO, MCC. and LINSINGEN, LV., 2009. Macrófitas aquáticas do Município de General Carneiro, Paraná, Brasil. Biota Neotropica, vol. 9, no. 3, p. 1-8.

CHASE, MW. and REVEAL, JL., 2009. A phylogenetic classification of the land plants to accompany APG III. Botanical Journal of the Linnean Society, vol. 161, p. 122-127. http://dx.doi. org/10.1111/j.1095-8339.2009.01002.x

COLWELL, RK., 2009. EstimateS, Version 8.2: Statistical Estimation of Species Richness and Shared Species from Samples (Software and User's Guide). Freeware for Windows and Mac OS. Available from: <http://viceroy.eeb.uconn.edu/estimates>.

COOK, CDK., 1996. Aquatic and wetland plants of India. Oxford: Oxford University Press. $385 \mathrm{p}$

CUNHA, NL and FISCHER, E., 2009. Breeding system of tristylous Eichhornia azurea (Pontederiaceae) in the southern Pantanal, Brazil. Plant Systematics and Evolution, vol. 280, p. 53-58. http://dx.doi.org/10.1007/s00606-009-0170-z

DA SILVA, CJ. and PINTO-SILVA, V., 1989. Macrófitas aquáticas e as condições físicas e químicas dos "alagados", "corixos", e rios, ao longo da rodovia Transpantaneira- Pantanal Matogrossense (Poconé - MT). Revista Brasileira de Biologia = Brazilian Journal of Biology, vol. 49, p. 691-697. 
DAMASCENO-JÚNIOR, GA., SEMIR, J., SANTOS, FAM. and LEITÃO-FILHO, HF., 2004. Tree mortality in a riparian forest at Rio Paraguai, Pantanal, Brazil, after an extreme flooding. Acta Botanica Brasilica, vol. 18, p. 839-846. http://dx.doi.org/10.1590/ S0102-33062004000400014

ESTEVES, FA., 1998. Fundamentos de limnologia. Rio de Janeiro: Editora Interciência/FINEP. 575 p.

FERREIRA, FA., MORMUL, RP., THOMAZ, SM, POTT, A. and POTT, VJ., 2011. Macrophytes in the upper Paraná river floodplain: checklist and comparison with other large South American wetlands. Revista de Biología Tropical, vol. 59, no. 2, p. 541-556. PMid:21717850.

FORTNEY, RH., BENEDICT, M., GOTTGENS, JF., WALTERS, TL., LEADY, BS and RENTCH, J., 2004. Aquatic plant community composition and distribution along an inundation gradient at two ecologically-distinct sites in the Pantanal region of Brazil. Wetlands Ecology and Management, vol. 12, p. 575-585. http:// dx.doi.org/10.1007/s11273-005-1763-0

FRANKLIN, P., MICHAEL, D. and WHITEHEAD, P., 2008. Flow controls on lowland river macrophytes: A review. Science of the Total Environment, vol. 400, p. 369-378. PMid:18644618. http://dx.doi.org/10.1016/j.scitotenv.2008.06.018

FREY, R., 1995. Flora and Vegetation of "Las Piedritas" and the Margin of Laguna Caceres, Puerto Suarez, Bolivian Pantanal. Bulletin of the Torrey Botanical Club, vol. 122, p. 314-319. http:// dx.doi.org/10.2307/2996324

GUIMARÃES, AJM., ARAÚJO, GM. and CORRÊA, GF., 2002. Estrutura fitossociológica em área natural e antropizada de uma vereda em Uberlândia, MG. Acta Botanica Brasilica, vol. 16, no. 3 , p. 317-329.

JAMES, EK., LOUREIRO, MF., POTT, A., POTT, VJ., MARTINS, CM., FRANCO, AA. and SPRENT, JI., 2001. FloodingTolerant Legume Symbioses from the Brazilian Pantanal. New Phytologist, vol. 150, p. 723-738. http://dx.doi.org/10.1046/j.14698137.2001.00126.x

JUNK, WJ., BAYLEY, PB. and SPARKS, RE., 1989. The flood pulse concept in River-Floodplain Systems. Canadian Special Publication of Fisheries and Aquatic Sciences, vol. 106, p. 110-127.

JUNK, WJ., BROWN, M., CAMPBELL, IC., FINLAYSON, M., GOPAL, B., RAMBERG, L. and WARNER, BG., 2006. The comparative biodiversity of seven globally important wetlands: a synthesis. Aquatic Sciences, vol. 68, p. 400-414. http://dx.doi. org/10.1007/s00027-006-0856-z

KOZERA, C., KUNIYOSHI, YS., GALVÃO, F. and CURCI, GR., 2009. Composição florística de uma formação pioneira com influência fluvial em Balsa Nova, PR, Brasil. Floresta, vol. 39, no. 2 , p. 309-322.

KUFNER, DCL., 2009. Estudo florístico em lagoa de meandro no Pantanal de Miranda, Centro-Oeste do Brasil. Campo Grande: Universidade Federal de Mato Grosso do Sul. 20 p. Dissertação de Mestrado em Biologia Vegetal.

LIMA, ZM., PAULA, AM., SÉRGIO, EC., SOARES, CR. and MACEDO, M., 1999. Aspectos ecológicos da dispersão em "camalotes" de macrófitas aquáticas na Baía Piuvial, Pantanal de Poconé - MT. In Anais do $2^{\circ}$ Simpósio sobre Recursos Naturais e Sócio-Econômicos do Pantanal, Manejo e Conservação, 1999. Corumbá: Embrapa Pantanal. p. 381-385.
MALTCHIK, L. and CALLISTO, M., 2004. The use of rapid assessment approach to discuss ecological theories in wetland systems, southern Brazil. Interciencia, vol. 29, p. 219-223.

MALTCHIK, L., ROLON, AS. and SCHOTT, P., 2007. Effects of hydrological variation on the aquatic plant community in a floodplain palustrine wetland of southern Brazil. Limnology, vol. 8, p. 23-28. http://dx.doi.org/10.1007/s10201-006-0192-y

MORMUL, RP., FERREIRA, FA., MICHELAN, TS., CARVALHO, P., SILVEIRA, MJ. and THOMAZ, SM., 2010. Aquatic macrophytes in the large, sub-tropical Itaipu Reservoir, Brazil. Revista de Biología Tropical, vol. 58, no. 4, p. 1437-1452. PMid:21246998.

NEIFF, JJ., PATIÑO, CAE., CASCO, SL., 2005. Atenuación de las crecidas por los humedales del Bajo Paraguay. In: CAPATTO, J. and PETEÁN, J. (Eds.). Humedales fluviales de América del Sur. Hacia un manejo sustentable. Argentina: Fundación Proteger. p. $261-276$

OKSANEN, J., KINDT, R., LEGENDRE, P., O'HARA, B., SIMPSON, GL., SOLYMOS, P., HENRY, M., STEVENS, H. and WAGNER H., 2009. Vegan: Community Ecology Package. R package version 1.15-4. Available from: <http://CRAN.R-project. org/package $=$ vegan $>$.

PADIAL, AA., BINI, LM. and THOMAZ, SM., 2008. The study of aquatic macrophytes in Neotropics: a scientometrical view of the main trends and gaps. Brazilian Journal of Biology, vol. 68, no. 4 suppl., p. 1051-1059. http://dx.doi.org/10.1590/S151969842008000500012

PADIAL, AA., THOMAZ, SM. and AGOSTINHO, AA., 2009. Effects of structural heterogeneity provided by the floating macrophyte Eichhornia azurea on the predation efficiency and habitat use of the small Neotropical fish Moenkhausia sanctaefilomenae. Hydrobiologia, vol. 624, p. 161-170. http://dx.doi.org/10.1007/ s10750-008-9690-8

PETRY, P., BAYLEY, PB., and MARKLE, DF., 2003. Relationships between fish assemblages, macrophytes and environmental gradients in the Amazon River floodplain. Journal of Fish Biology, vol. 63, p. 547-579. http://dx.doi.org/10.1046/j.1095-8649.2003.00169.x

PINDER, L. and ROSSO, S., 1998. Classification and ordination of plant formations in the Pantanal of Brazil. Plant Ecology, vol. 36, p. 151-165. http://dx.doi.org/10.1023/A:1009796616824

PITELLI, RLCM., TOFFANELLI, C., VIEIRA, E., PITELLI, RA. and VELINI, ED., 2008. Dinâmica da comunidade de macrófitas aquáticas no reservatório de Santana, RJ. Planta Daninha, vol. 26, no. 3, p. 473-480.

PIVARI, MO., POTT, VJ. and POTT, A., 2008. Macrófitas aquáticas de ilhas flutuantes (baceiros) nas sub-regiões do Abobral e Miranda, Pantanal, MS, Brasil. Acta Botanica Brasilica, vol. 22, no. 2, p. 563-571. http://dx.doi.org/10.1590/S0102-33062008000200023

POTT, A., POTT VJ., SCIAMARELLI, A., SARTORI ALB., SCREMIN-DIAS, E., JACQUES, EL., ARAGAKI, S., NAKAJIMA, JN., ROMERO R., Cristaldo, ACM., DAMASCENO-JUNIOR, GA., 2006. Flora-Inventário das Angiospermas no Complexo Aporé-Sucuriu (p. 45-66). In: PAGOTTO, TCS. and SOUZA, PR. (Orgs.). Biodiversidade do Complexo Aporé-Sucuriú: subsídios à conservação e ao manejo do Cerrado: Área prioritária 316-Jauru. Campo Grande: Editora UFMS. 308 p.

POTT, VJ. and POTT, A., 1997. Checklist das macrófitas aquáticas do Pantanal, Brasil. Acta Botanica Basilica, vol. 11, no. 2, p. 215-227.

-, 2000. Plantas Aquáticas do Pantanal. Brasília: Embrapa. 404 p. 
-, 2003. Dinâmica da vegetação aquática do Pantanal. In THOMAZ, SM. and BINI, LM. (Eds). Ecologia e manejo de macrófitas aquáticas. Maringá, PR: Editora da Universidade Estadual de Maringá. p. 145-162.

POTT, VJ., POTT, A., LIMA, LCP., MOREIRA, SN. and OLIVEIRA, AKM., 2011. Aquatic macrophyte diversity of the Pantanal wetland and upper basin. Brazilian Journal of Biology, vol. 71, no. 1 suppl., p. 255-563. PMid:21537598.

POTT, VJ., BUENO, NC., PEREIRA, RAC., SALIS, SM. and VIEIRA, NL., 1989. Distribuição de macrófitas aquáticas numa lagoa na fazenda Nhumirim, Nhecolândia, Pantanal, MS. Acta Botanica Brasilica, vol. 3, no. 2, p. 153-168.

PRANCE, GT. and SCHALLER, GB., 1982. Preliminary study of some vegetation types of the Pantanal, Mato Grosso, Brazil. Brittonia, vol. 34, p. 228-251. http://dx.doi.org/10.2307/2806383

R Development Core Team, 2010. R: A language and environment for statistical computing. Vienna: R Foundation for Statistical Computing. Available from: <http://www.R-project.org $>$.

ROCHA, AES. and LINS, A., 2009. Checklist das Poaceae de áreas inundáveis e inundadas do nordeste do estado do Pará. Acta Amazonica, vol. 39, no. 4, p. 763-772.

RODRIGUES, RB., 2010. Estrutura da comunidade de macrófitas aquáticas e características ambientais das lagoas da sub-região da Nhecolândia, Pantanal de Corumbá, MS, Brasil. Campo Grande: Universidade Federal de Mato Grosso do Sul. 37 p. Dissertação de Mestrado em Biologia Vegetal.

SANTOS, AM. and ESTEVES, FA., 2004. Influence of water level fluctuation on the mortality and aboveground biomass of the aquatic macrophyte Eleocharis interstincta (Vahl) Roemer et Schultes. Brazilian Archives of Biology and Technology, vol. 47, p. 281-290. http://dx.doi.org/10.1590/S1516-89132004000200016

SANTOS, AM. and THOMAZ, SM. 2007. Aquatic macrophytes diversity in lagoons of a tropical floodplain: The role of connectivity and water level. Austral Ecology, vol. 32, p. 177-190. http:// dx.doi.org/10.1111/j.1442-9993.2007.01665.x

,- 2008 . Short term fluctuations and succession trends in tropical floodplain vegetation measured by correspondence analysis. Brazilian Archives of Biology and Technology, vol. 51, p. 581-591. http://dx.doi.org/10.1590/S1516-89132008000400016

SILVA, JSV. and ABDON, MM., 1998. Delimitação do Pantanal brasileiro e suas sub-regiões. Pesquisa Agropecuária Brasileira, vol. 33, p. 1703-1711.

SORIANO, BMA., 1997. Caracterização climática de Corumbá, MS. Corumbá: Embrapa. 25 p. Boletim de pesquisa, no. 11.

THOMAZ, SM., BINI, LM. and BOZELLI, RL., 2007. Floods increase similarity among aquatic habitats in river-floodplain systems. Hydrobiologia, vol. 579, p. 1-13.

THOMAZ, SM., DIBBLE, ED., EVANGELISTA, LR., HIGUTI, J. and BINI, LM., 2008. Influence of aquatic macrophyte habitat complexity on invertebrate abundance and richness in tropical lagoons. Freshwater Biology, vol. 53, p. 358-367.

THOMAZ, SM., CARVALHO, P., PADIAL, AA. and KOBAYASHI, JT., 2009. Temporal and spatial patterns of aquatic macrophyte diversity in the Upper Paraná River floodplain. Brazilian Journal of Biology, vol. 69, no. 2 suppl., p. 617-625. PMid:19738968. 
